\title{
Covid-19 treatment-induced neuropsychiatric adverse effects
}

\author{
C.A. Carrajo García*, E.B. Alonso Sánchez, D. Hernández Huerta, J. Gómez-Arnau \\ Department of Psychiatry, University Hospital Ramón y Cajal, Madrid, Spain
}

*Corresponding author: C.A. Carrajo García, Department of Psychiatry, University Hospital Ramón y Cajal, Madrid, Spain

Received date: June 20, 2020; Accepted date: August 05, 2020; Published date: August 11, 2020

Citation: Carrajo García C.A., Alonso Sánchez E.B., Hernández Huerta D., Gómez-Arnau J., (2020) Covid-19 treatment-induced neuropsychiatric adverse effects. J. Archives of Medical Case Reports and Case Study. 3(2); DOI:10.31579/2692-9392/015

Copyright: () 2020 C.A. Carrajo García, This is an open access article distributed under the Creative Commons Attribution License, which permits unrestricted use, distribution, and reproduction in any medium, provided the original work is properly cited.

Severe Acute Respiratory Syndrome coronavirus 2 (SARS-CoV-2) was first notified in Wuhan, China, in December 2019, and has rapidly spread worldwide, due to its high transmission rate. It has been identified as the causative agent of the now termed coronavirus disease (COVID-19), which can range from mild condition to potentially fatal respiratory distress syndrome [1]. There is no vaccine or specific antiviral drug regime used to treat ill patients. However, the therapeutic potential of certain drugs used for other diseases has led to their offlabel use for COVID-19, such as antiretroviral drugs (lopinavir-ritonavir, darunavir, remdesivir), corticosteroids, biological treatments (tocilizumab), antiparasitics (hydroxychloroquine and nitazoxanide) and antibiotics (azithromycin) [2]

COVID-19 represents a major challenge in the field of psychiatry, as both the virus and the medications used to treat it may induce neurologic and psychiatric symptoms [3]. The main aim of this letter is to briefly review COVID-19 treatmentinduced neuropsychiatric adverse effects.

Steps in coronavirus replication are potential targets for Antiretroviral drugs. These drugs may produce undesirable effects on the central and peripheral nervous systems, highly variable in frequency and severity, depending on the biological mechanism involved. Cytochrome p450 enzymes are affected by protease inhibitors (lopinavir, ritonavir, darunavir) which could lead to neurotoxicity by altering plasma concentrations of multiple psychotropic drugs. Despite their poor penetration through the blood-brain barrier they are inherently neurotoxic, showing perioral $(25 \%)$ and peripheral $(7 \%)$ paresthesias, as well as changes in taste (12\%) since the first month of treatment [4]. The lopinavirritonavir combination has been associated with bilateral sensorineural hearing loss after 4 weeks of treatment, and with the appearance of depressive symptoms. Darunavir, however, has not shown increased neurotoxicity [4].

Corticosteroids modulate hyper inflammation and inhibit immune responses that are vital for the host defense against the virus. However, side-effects are common, appearing in up to $90 \%$ of patients with more than 60 days of treatment, according to the dose range and route of administration. Short course high-dose corticosteroid treatment, as occurs in COVID-19, may cause delirium and changes in mood (with a frequency of up to $52 \%$ of patients treated with more than $20 \mathrm{mg}$ a day of prednisone during 3 months) [5], being mania and hypomania more frequently observed than depression. Memory deficits and cognitive impairment have also been described more often due to hypokalemia tan neurotoxicity.

Azithromycin is an antibiotic that has been proven to be active in vitro against Zika and Ebola viruses by interfering with their protein synthesis. The distinctive feature of azithromycin is its high and sustained concentration in brain tissue, presumably due to its amphipathic properties and high volume of distribution. Neurological adverse events reported in premarketing clinical trials were mild, occurring in less than $1 \%$ of patients. Serious adverse neuropsychiatric effects such as delirium have been rarely reported in adults [6].

Despite there is no clear evidence of its efficacy it seems relevant to mention chloroquine and related agents, whose compassionate use is based on the role that they could have in stopping the cytokine storm which contributed to acute respiratory distress caused by SARS-CoV-2. These treatments are able to induce neuropsychiatric symptoms from mild (mood lability, nervousness) to severe degree (psychosis, suicidal tendencies) and the high dose administration is a predictor of complications [7].

Tocilizumab is a humanized monoclonal antibody approved for the treatment of rheumatoid arthritis (RA). It plays a significant role in IL-6 receptor blockade, which by itself does not solve problems with systemic inflammatory response síndrome but could contribute to reduce the cytokine storm. Besides there is no evidence in the literatura that there is a direct link between IL-6 level and mental disorders, inhibition of IL-6 may also be responsible for improvements in depression, fatigue and pain and common extra-articular features of RA [8].

Treatments with interferon, remdesivir and nitazoxanide are also being repurposed. In particular, remdesivir, a nucleotide analogue prodrug, is considered a promising antiviral agent in the treatment of critically ill patients, as it causes a blockade in viral RNA polymerases reducing the viral load and alleviating pathological damage to lung tissue. Although there is no evidence of neuropsychiatric side-effects, a close monitoring is necessary in order to minimize risks [9].

Therapeutic recommendations and guidelines for covid-19 are still constantly changing. With several ongoing clinical trials at this time, it is expected that some drugs will be discarded while new ones will increase the available therapeutic arsenal. Given the increasing spread of COVID19 , it is important that psychiatrists stay up-to-date on treatments and 
remain aware of the occurrence of neuropsychiatric side effects, even not previously described.

\section{References}

1. Li Q, Guan X, Wu P, Wang X, Zhou L, Tong Y, et al. (2020) Early transmission dynamics in Wuhan, China, of novel coronavirus-infected pneumonia. $\mathrm{N}$ Engl $\mathrm{J}$ Med 382(13):1199-1207.

2. Kalil AC. (2020) Treating COVID-19-off-label drug use, compassionate use, and randomized clinical trials during pandemics. JAMA
3. Conde Cardona G, Quintana Pájaro LD, Quintero Marzola ID, Ramos Villegas Y, Moscote Salazar LR. (2020) Neurotropism of SARS-CoV 2: mechanisms and manifestations.

4. Abers MS, Shandera WX, Kass JS. (2014) Neurological and psychiatric adverse effects of antiretroviral drugs. CNS Drugs 28(2):131-145.

5. Fardet L, Flahault A, Kettaneh A, Tiev KP, Généreau T, Tolédano C, et al. (2007) Corticosteroid-induced clinical adverse events: frequency, risk factors and patient's opinion. Br J Dermatol 157(1):142-148.
This work is licensed under Creative Commons Attribution 4.0 License

To Submit Your Article Click Here: Submit Article

DOI: $10.31579 / 2692-9392 / 015$
Ready to submit your research? Choose Auctores and benefit from:

* fast, convenient online submission

* rigorous peer review by experienced research in your field

* rapid publication on acceptance

* authors retain copyrights

* unique DOI for all articles

* immediate, unrestricted online access

At Auctores, research is always in progress.

Learn more www.auctoresonline.org/journals/archives-of-medical-casereports-and-case-study 